\title{
近世期の弘前藩御蔵所の空間構成に関する研究 \\ STUDY ON SPATIAL STRUCTURES OF OKURA-SYO OWNED \\ BY HIROSAKI DOMAIN IN THE EDO PERIOD
}

\author{
相 模 誓 雄*1
}

\section{Chikao SAGAMI}

\begin{abstract}
The purpose of this study is to clarify the characteristics of spatial structures of Okura-syo owned by Hirosaki domain, and the factors of forming the space. It developed that Okura-syo in Hirosaki domain territory were characterized by next two things. The first one, there was a standard form. The second one, the only long eaves were provided on the main building of Okura-syo, in comparison with Okura-syo in the heavy snowfall area. As the factors of forming the space, it was mentioned that there was a passage inside of Okura, and the permanent inspection station was not built.
\end{abstract}

Keywords : Storehouse, Premises, Spatial structure, Eaves 蔵, 屋敷, 空間構成, 庇

\section{1. はじめに}

筆者は、日本の豪雪地帯における近世期の御蔵所について研究し てきた。御蔵所は、幕府や諸藩が領内における年貢米の徵収及び迴 米に用いた米の収納施設である。防衛防犯のため卌などで囲まれた 広い敷地内には、複数の御蔵が建ち並んでおり、検查所注 1$)$ や番屋 などが設けられていた。これらの建物配置には藩毎に共通性（以後 型式）が見られた。御蔵の戸前には長庇があり、これが検查所注 2) や 米俵の仮置き場注3) 等として用いられた地域があった注 4 )。また、加 賀藩領において長庇は、庇本来の目的である戸口の保護や上記の事 柄に加えて、御蔵相互を結ぶ廊下としての役割があったことが考え られた注5)。

弘前藩もまた豪雪地帯にあり、領内の所々に御蔵所を設けて年貢 米の徴収及び廻米を行った (Fig. 1)。これらの御蔵所の多くに常設 の検查所は見られない。しかし、御蔵の戸前に形成される検查所の 代りを果たす長庇（Fig. 2）も僅かである。このような御蔵所は他 藩にはあまり見られないものである注 6$)$ このことから本研究は、弘 前藩御蔵所を取り上げ、その空間構成の特徴及びその形成要因を明 らかにすることを目的とする。

弘前藩は、迴米のため領内の各御蔵所で集めた年貢米を、岩木川 水運や陸運を用いて青森や鯵ヶ沢といった移出港へ運しだ。そして、 これらの港から海運を用いて米市場の江戸や大坂へ運んだのである。 宝暦 8 年 (1758) の「津軽見聞記」注7) に、「所々御蔵所之覚 金木、 八幡、木造、五所川原、板屋野木、床舞、藤崎、石渡、高杉、深浦、 弘前、鰺ヶ沢、浪岡、青森、以上十四ヶ所」とある。このうち、五

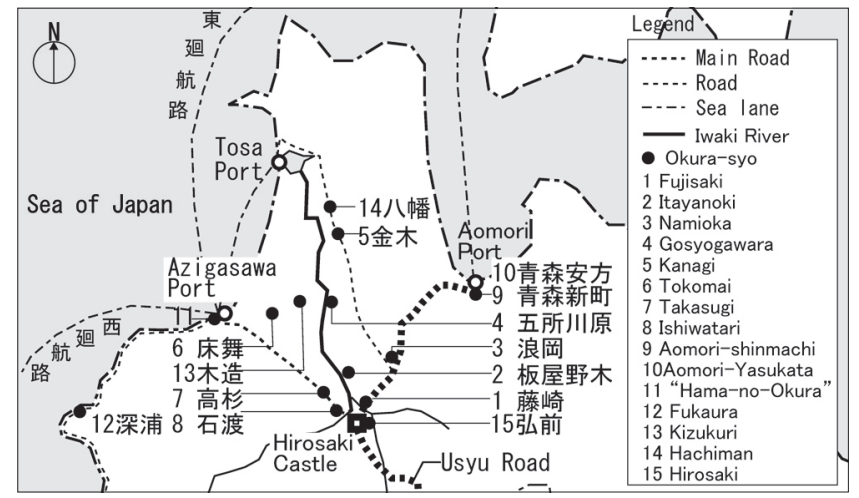

Fig. 1 The distribution of Okura-syo in the Hirosaki domain territory

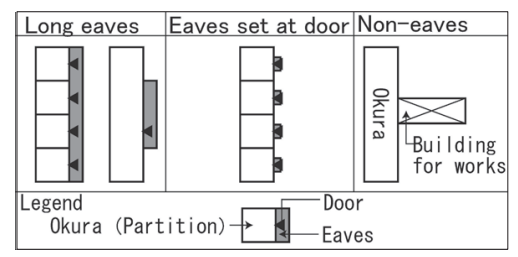

Fig. 2 The diagram of the front of Okura

所川原、板屋野木、藤崎、浪岡の各御蔵所は収納量 1 万 8 千俵以上 の比較的大規模なもの注 8)、金木、八幡、木造、床舞、石渡、高杉の 各御蔵所は、それ以下の比較的小規模なものと推測される。以上の 御蔵所は、村や町において年貢米徴収のみに用いられた。一方、青 森や鰺ヶ沢の各御蔵所は、移出港において迴米にも用いられた。本

\footnotetext{
$* 1$ 仙台高等専門学校総合工学科 准教授. 博士 (工学)
} 
研究ではこれらの御蔵所を対象とする。以後御蔵所は、括弧を付け て名称のみを記す。

\section{2. 既往研究、手順}

近世期の幕府や諸藩が地方に設けた御蔵所は、建築遺構が希少で あることから、これまで建築史学における研究は殆ど見られなかっ た。しかし、筆者は見取図や郷土史の文献などを用いて、藩毎に建

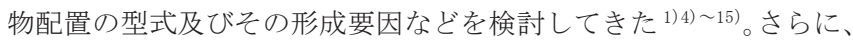
御蔵の庇についても検討した ${ }^{3)}$ 。弘前藩御蔵所の建築遺構は、弘前 市亀甲町にある。弘前城下の亀甲御蔵所注 9) の一部の御蔵 (Fig. 5)

で、慶応元年 (1865) に建築された梁行 4 間、桁行 15 間の土蔵一棟 である。校舎などに転用され、現在は工房兼店舗として活用されて いるため、戸口などの改変がある。筆者は過去の報告で弘前藩御蔵 所に触れている。一つは御蔵所を有した板屋野木や五所川原の河港 集落を取り上げ、御蔵所が集落の空間構成に及ぼした影響ついて検 討したものである ${ }^{16)}$ 17)。また一つは、盛岡藩御蔵所の空間構成の特 質を明らかにするため、東北地方の諸藩の御蔵所の代表的な建物配 置を示した ${ }^{12)}$ 。しかし、弘前藩御蔵所の型式の成り立ち、建築構成 については検討していない。

本研究は、まず、弘前藩御蔵所の実態を明らかにする。第一に空 間構成要素及び型式、第二に庇や御蔵の内部である。次に、弘前藩 御蔵所の標準形、長庇の機能について検討し、最後に空間構成の特 徵及びその形成要因についての考察を試みることにする。

弘前藩御蔵所の建物配置や建築構成が知られる史料に、八木橋文 庫「津軽藩政時代之公衙蔵庫古圖式」注 10)（Fig. 3(2)右図、(3)、(4)左 図）や「津軽藩諸役所倉庫圖式一部」注 11) の見取図がある（Fig. 3 (5) (9)。これらの図は写しであり、原図の所在及び作製年は明らか でない。しかし、(1)、(2)右図, (4)左図, (6), (9)、藩政後期の御蔵所の 姿が描かれていると考えられる注 12$)$ 。た、〈板屋野木〉に関する元 禄 5 年 (1692) の見取図 (Fig. 32)左図)、〈五所川原〉に関する明 治維新当時の見取図 (Fig. 3(4)右図)、鯵ヶ沢港の御蔵が描かれた町 絵図（Fig. 4）も見られる。本稿では、これらなどの見取図等の絵 図史料を用いて検討することにする。

\section{3. 空間構成の実態}

\section{1 空間構成要素}

前述した 14 ケ所の御蔵所のうち、見取図等の史料から敷地範囲、 建物の種別及びそれらの配置が知られる御蔵所は 9 ケ所である (Fig. 3)。青森港や鯵ヶ沢港には複数の蔵場があった。後者については、

「濱ノ御蔵」、「沢ノ御蔵」、御仮屋の敷地内にあったが注 13$)$ 、複数の 御蔵が見られる「濱ノ御蔵」を取り上げる。青森港には「安方御蔵」 もあった（Fig. 4)。以上の 11 ケ所の御蔵所を対象とする。なお、 元禄 5 年（1692）の〈板屋野木〉は、「上蔵」と「下之蔵」に分かれて いるが、型式の検討においては中心的な位置を占めている「上蔵」 を対象としたい。Table 1 に、Fig. 3 に描かれている御蔵等の建物 の種別を整理した。御蔵以外の施設に注目すると、御長屋や検査所 が見られる。

\section{1.1 御長屋}

年貢米徴収のみに用いられた全ての御蔵所に御長屋がある注 ${ }^{14)}$ 。 これは、御蔵奉行、立合や枰取（検查人）といった役人の居所であ
Table 1 Factors of spatial structure, Type of building arrangement

\begin{tabular}{|c|c|c|c|c|c|c|}
\hline & Okura & $\begin{array}{l}\text { Inspection } \\
\text { station }\end{array}$ & $\begin{array}{c}\text { Onaga } \\
\text { ya*4 }\end{array}$ & $\begin{array}{l}\text { Guard } \\
\text { house }\end{array}$ & \begin{tabular}{|c|} 
Type of \\
building \\
arrangement
\end{tabular} & $\begin{array}{l}\text { Other } \\
\text { buildings }\end{array}$ \\
\hline 1 Fuiisaki & 3 & $* 3$ & 1 & & Enclosure & \\
\hline 2Itavanoki*1 & 2 & & & & II & 長屋門 \\
\hline 2 Itavanoki $* 2$ & 3 & $* 3$ & 1 & & Parallel & \\
\hline 3 Namioka & 4 & $* 3$ & 1 & & Enclosure & \\
\hline 4 Gosvogawara & $4 \sim 5$ & & 1 & & II & \\
\hline 5 Kanagi & 2 & 1 & 1 & & II & 板蔵、木屋 \\
\hline 6 Tokomai & 1 & 1 & 1 & & & \\
\hline 7 Takasugi & 3 & & 1 & & Parallel & \\
\hline 8 Ishiwatari & 3 & & (1) & & II & \\
\hline 9 Aomorishinmachi & 8 & $\frac{1}{" K}$ & & & Enclosure $* 5$ & 井戸屋 \\
\hline
\end{tabular}

*1 The year 1692 (元禄 5 年), “Kamikura" *2 Late shogunate (潘政

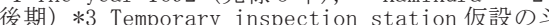
*5 If an inspection station is taken off. 検査所を除いた場合

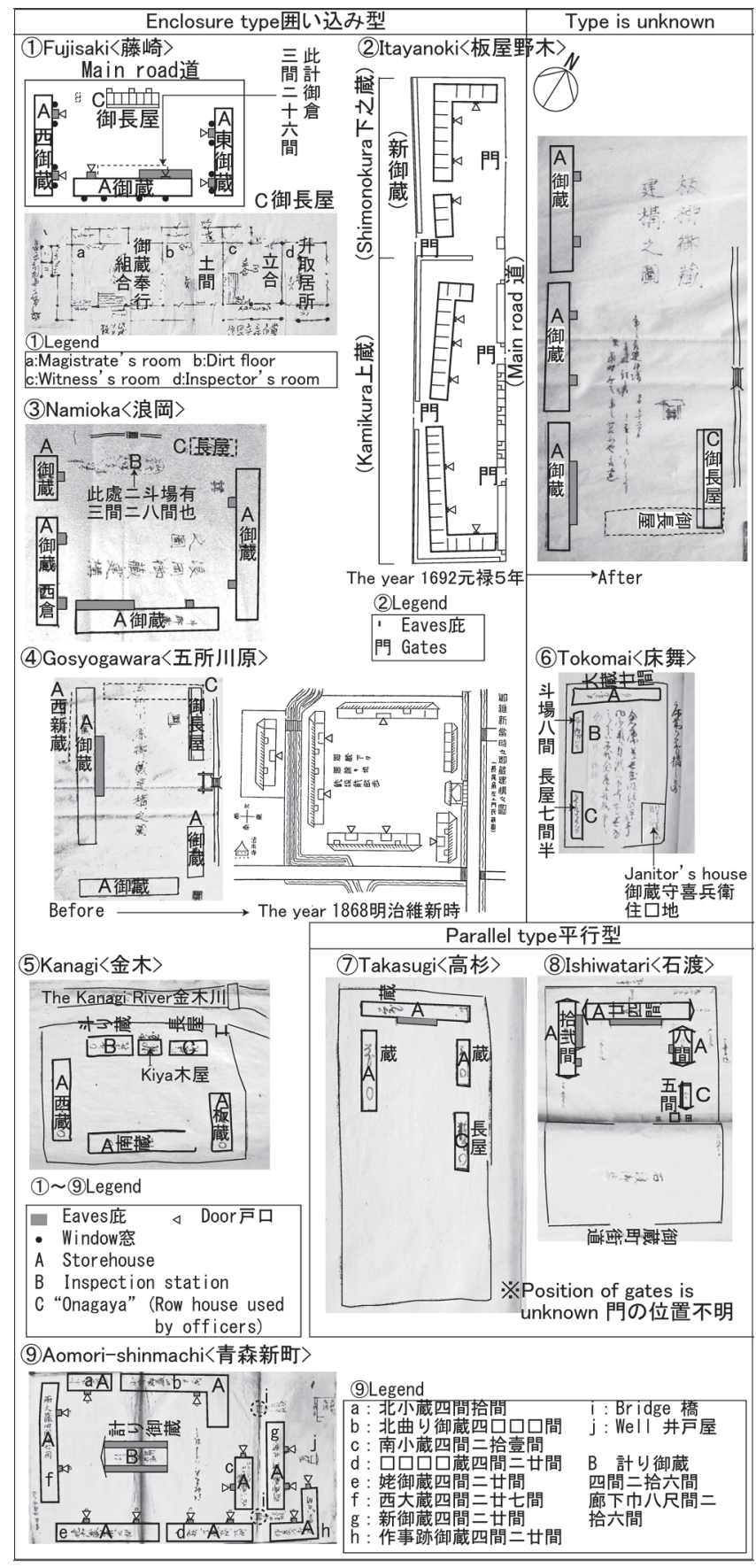

Fig. 3 Plans of Okura-syo owned by Hirosaki domain(1),(2)Right,(4)Left, 6.9) were drawn up in late shogunate) 
った（Fig. 3(1) 注 15)。門または道の位置が知られる御蔵所におい て御長屋は、門または道寄りに配置されている(Fig. 3(1)〜 (6)、(8))。 以上、御長屋は年貢米徴収を主な目的とした弘前藩御蔵所に必須の 施設であり、敷地への入口を意識した空間構成であったことが知ら れる。

\subsection{2 検査所}

大規模な御蔵所の見取図（Fig. 31)〜 (4)）に検查所は描かれてい ない。但し、〈板屋野木〉に関寸る「板柳御蔵建構之圖」(同図(2)右) に、「年々取建斗場 間二十二間（中略）当時無之年々苫小や取建」 とあり、簡易な検查所が年毎に建造されていたことがわかる注 ${ }^{16)}$ 。

一方、〈藤崎〉では、Fig. 311 において「計御倉」が敷地奥に位置す る御蔵の正面に点線で描かれている。しかし、文献 21）掲載の「藤 崎御蔵構之図」などではこのような部分は見られない。〈浪岡〉では、 敷地入口の辺りに「斗場有」と文字のみで記されている。これらの 検查所も実態が示されていないことから、〈板屋野木〉と同様なもの であった可能性が高い。

小規模な御蔵所においては、〈金木〉に「斗り蔵」(Fig. 35) 、〈床 舞〉に「斗場」(Fig. 36) 无見られる。これらの検查所は常設の建 物と見られる。Fig. 3(5)6に長庇は見られないので、常設の建物を 検查所としたのであろう。

移出港の〈青森新町〉の場合、貞享期 (1684〜) から元禄元年 (1688) までの間に作製された「青森町絵図」（Fig. 49）のく青森新町〉に は文字のみで「計御蔵」と記されている。一方、藩政後期の Fig. 3 (9)に、「計り御蔵」が敷地の中央に描かれている。後者の検查所は 切妻屋根で、平側両面の下屋に幅 8 尺の「廊下」が見られる。なお、 ここにはく藤崎〉やく浪岡〉から馬で運ばれてくる大量の米が収納され 注 17)、迴米や払米となったので、効率的な検査及び収納のため、常 設の検查所を御蔵群の中心に配置したと考えられる。

以上、〈青森新町〉や長庇のない小規模な御蔵所 2 ヶ所を除くと、 弘前藩御蔵所において検查所は設けられず、大規模の御蔵所では仮 設であった。

\section{2 建物配置の型式}

各御蔵所の建物配置の共通性を見ると、〈藤崎〉、元禄 5 年 (1692) の〈板屋野木〉、〈浪岡〉、〈五所川原〉、〈金木〉では、御蔵や御長屋が 敷地境界に寄せて配置され、庭の四方を囲んでいる（Fig. 3(1)～(5)、

(9)）。筆者は過去の研究においてこのような建物配置の御蔵所を「囲 い込み型」として類型化した注 ${ }^{18)}$ 。

藩政後期の〈板屋野木〉については、3 棟の御蔵と御長屋が庭を 挟んで平行関係に配置されている。筆者は過去の研究においてこの ような建物配置の御蔵所を「平行型」として類型化した注 ${ }^{19)}$ 。〈板屋 野木〉については御蔵所の変遷が知られる。明和 3 年 (1766) の地震 で「上蔵」と「下之蔵」の両方が潰れた注 20)。藩政中期は囲い込み型 であったが、再建後に Fig. 3(2)右図の建物配置になったと考えられ る注 21)。

一方、〈床舞〉、〈高杉〉、〈石渡〉は、庭の四方が建物で囲まれてい ない (Fig. 3(6)〜8)。〈高杉〉と〈石渡〉については、2 棟の御蔵が平 行関係に配置されているので、「平行型」に類型化できる。一方、く 床舞〉は、御蔵所の形式を有しているものの、御蔵が一棟であるので、 型式の検討は難しい注 22)。平行型の〈高杉〉、〈石渡〉は小規模な御蔵 所に分類した。敷地の門側は空地になっていて発展の余地を残して
Table 2 Number of Okura, Door, Eaves, Long eaves

\begin{tabular}{|c|c|c|c|c|c|c|}
\hline 7 & Okura & Door & Eaves & $\begin{array}{l}\text { Long } \\
\text { eaves }\end{array}$ & $\begin{array}{l}\text { Position of the } \\
\text { long eaves in } \\
\text { the site } * 5\end{array}$ & $\begin{array}{c}\text { Number of the door } \\
\text { or eaves about a } \\
\text { Okura } * 3 * 5\end{array}$ \\
\hline 1.Fuiisaki & 3 & 6 & 5 & 1 & Back & 2 \\
\hline 2 Itavanoki $* 1$ & 2 & 6 & 6 & & & 3 \\
\hline 2 Itavanoki $* 2$ & 3 & - & 4 & 1 & Back & 2 \\
\hline 3 Namioka & 4 & - & 6 & 1 & Back & 2 \\
\hline 4 Gosvogawara & $4 \sim 5$ & 7 & - & 1 & Back & 2 \\
\hline 5 Kanagi & 2 & & & & & \\
\hline 6 Tokomai & 1 & & & & & \\
\hline 7 Takasugi & 3 & - & - & 1 & (Back) & (2) \\
\hline 8 Ishiwatari & 3 & - & 2 & 2 & Back & $(2)$ \\
\hline 9 Aomorishinmachi & 8 & 14 & 14 & 2 & Center $* 4$ & 2 \\
\hline
\end{tabular}
*1 The year 1692 (元禄 5 年), “Kamikura” $* 2$ Late shogunate (藩政 後期 $) * 3$ The maximum $* 4$ on both side of the inspection station $* 5(\quad)$ is a guess

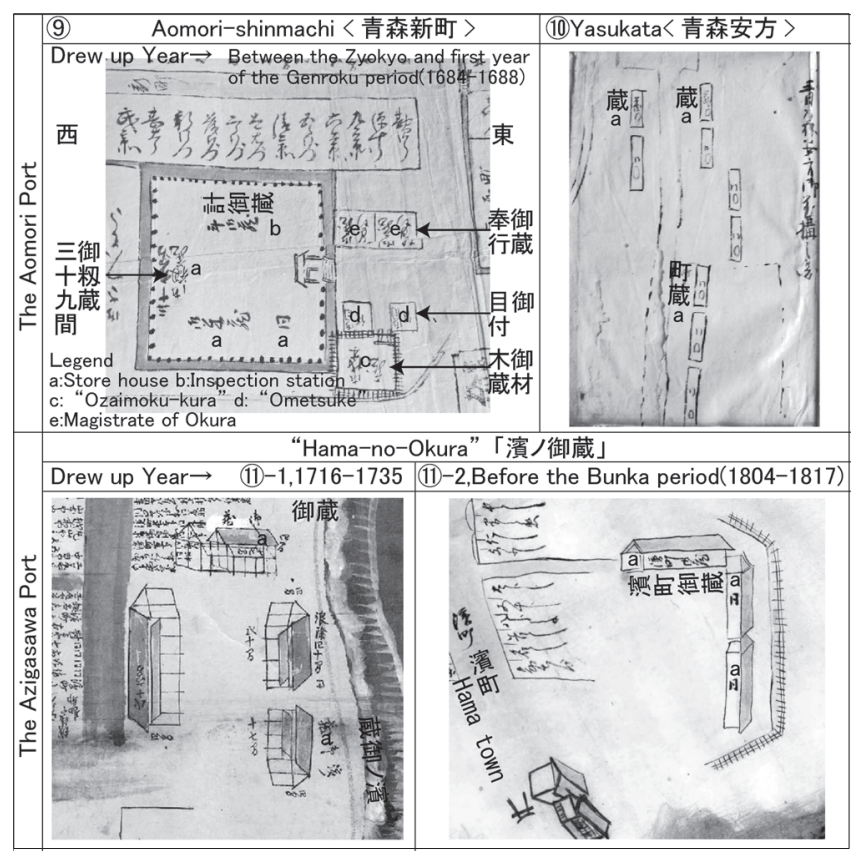

Fig. 4 The drawings of Okura located at the port

おり、型式形成途中の御蔵所と見られなくもない。しかし、御長屋 の棟が、前記した囲い込み型の御蔵所では門が開かれる敷地辺と平 行関係に配置されるのに対して、これらの御蔵所では直交しており、 本稿では、両者は型式の異なるものと考える。なお、〈高杉〉につい ては、門の位置が知られないが、Fig. 3(7)の下側の辺に門が開かれ ていた可能性が高いだろう。

鯵ヶ沢港の「濱ノ御蔵」は、前掲注 11)で述べたように御蔵所の 体を成していたとは見られないが、享保期（1716～1735）頃の「鰺 ケ沢町絵図」(Fig. 411-1) では、4 棟の建物（うち2 棟は「御蔵」 とある）がコの字形に、同じく文化年間（1804～1817）以前の「鯵 ケ沢町絵図」(Fig. 4111-2) では、3 棟の御蔵が L の字形に配置され ており、前者の建物配置は平行型のそれである注 23$) 。$

青森港のく青森新町〉については、藩政前期の町絵図に記されてい ることを前述したが、御蔵所内の建物として「御米蔵」 2 棟、「御粐 蔵」 1 棟、「計御蔵」 1 棟があった（Fig.49)）。これらの文字はコ の字形に配置されており、平行型と思われる。当初「計御蔵」は敷 地境界へ寄せて配置されていた。その後御蔵の数が増えたため、敷 地を東方へ拡張 (Fig. 399)。藩政後期には御蔵が囲い込み型を形成 
し、検查所が敷地中央へ移動したと推測される。前述の「安方御蔵」 については、作製年不明の「青森安方御蔵構之図」（Fig. 410）に9 棟の蔵が描かれるのみであり、これらの蔵は不規則に三列に配置さ れ、全ての蔵の棟が平行関係にあることのみが知られる。なお、本 図の中央の 1 棟に「町蔵」と朱書きされており、これより下側の 3 棟は御蔵でなかったと思われる。

\section{3 御蔵の建築構成}

\section{3.1 庇}

御蔵の庇には、戸口のみにかかる「戸前庇」と戸口以外の部分に も連続してかかる「長庇」がある(Fig. 2)。前述した弘前城下の御 蔵の遺構は、妻側両面に戸口が開かれている。うち 1 ケ所は掛子塗 りの戸をもつので旧来の戸口と見られる。これらの戸口には増築さ れた建物が接続しており、庇は見られない注24)（Fig. 5)。Table 2 は、御蔵所毎に庇の種類及び数、敷地における長庇の位置、御蔵 1 棟当たりの戸口もしくは戸前庇の数を一覧表にしたものである。御 蔵の戸口が知られる〈藤崎〉、〈五所川原〉や〈青森新町〉 (Fig. 31 (4)(9)）では、1 棟当たり最多で 2 ヶ所の戸口が開かれている。戸前 庇の数から、藩政後期の〈板屋野木〉、〈浪岡〉も同じと見てよいだ ろう。Fig. 3(4)の長庇を有する御蔵は 2 戸前と見られるので、〈高 杉〉や〈石渡〉の長庇を有寸る最大規模の御蔵も同様と思われる。 このことから藩政後期の弘前藩の場合、御蔵の戸口は最多で 2 ケ所 であったと推測される（Table 2)。常設の検查所がある御蔵所（2 ヶ所）を除く全ての年貢米徴収のみに用いられる御蔵所の御蔵に長 庇が見られる。その数は御蔵所当たり殆ど 1 ケ所と言ってよい。一 方、前掲の享保期（1716～1735）頃の鯵ケ沢町絵図の「濱ノ御蔵」 には、全ての米蔵に長庇が描かれている。但し、他の時代の鯵ケ沢 町絵図の「濱ノ御蔵」には、長庇は描かれていないので、このこと についてはさらなる検討を要する。

以上、弘前藩御蔵所では、迴米に用いられた藩政中期の鰺ヶ沢港 の「濱ノ御蔵」を除くと、戸前庇が多いことがわかる。敷地におけ る長庇の位置は、いずれも敷地奥の御蔵に設けられている (Table 2)。

\section{3.2 内部}

長庇がよく見られる地域において御蔵内部は小さく区画されてい た。その区画は囲いなどと呼ばれる注 25)。前述した弘前城下の御蔵 の遺構に、囲いの痕跡は見られない注 26)。一方、藩政中期のく板野野 木>の全ての御蔵に囲いが確認できる（Fig. 3(2)左図）。その原図に は柱が描かれており、標準的な囲いの広さは、間口 3 間、奥行 4 間 である。筆者の過去の研究によれば、加賀藩注 27)、鳥取藩注 28) など においては、囲い毎に戸口が開かれていた。しかし、〈板屋野木〉の 場合、囲いの数より戸口の数が少ない。Fig. 3(2)左図を詳しく見る と、御蔵の仕切りに開きがあり、各囲いが戸口側で繋がっている様 子が見て取れる。開きの幅は 1 間であり、各囲いの戸口側 1 間が通 路として機能すれば、戸口の数は最小限でよかったことになる注 29$) 。$ このような観点から見ると、〈藤崎〉、〈浪岡〉、〈五所川原〉、〈青森新 町〉なども御蔵の長さに対して戸口の数が少ない注 30$)$ (Table 2)。 なお、〈藤崎〉の 2 棟の御蔵や〈五所川原〉の各御蔵については、戸 口が開かれる壁面に高空が見られ、採光が図られている。以上のこ とから、〈板屋野木〉以外の御蔵所の御蔵も囲い及び内部通路があっ た可能性が高い。また、囲いがない場合でも、米俵は戸口とは反対 側に置かれるので、戸口から戸口への通り抜けは可能となる。

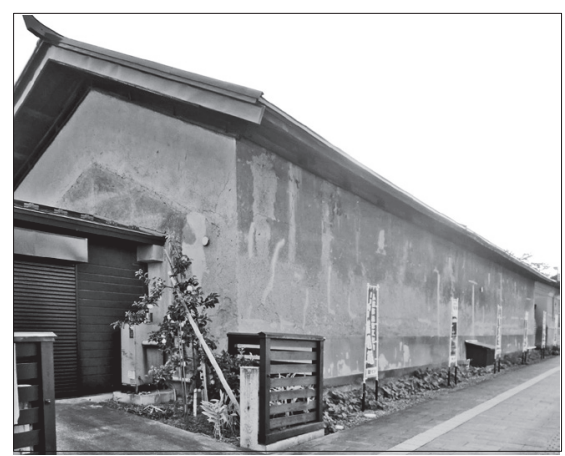

Fig. 5 Remains of Kiko-okura in Hirosaki City

\section{4. 考察}

\section{1 標準形}

\section{1.1 建物配置の型式}

弘前藩では、囲い込み型が多数を占めた。特に大規模の御蔵所に 顕著であった。平行型の〈高杉〉や〈石渡〉は、第一に建物の規模に対 して敷地が広く、空地が多い。従って、囲い込み型に成り難い条件 であった。このことはく床舞〉や御蔵所の焼失後に再建された藩政後 期の〈板屋野木〉にも当てはまるだろう。なお、平行型の御蔵所にお いても、敷地奥に最大規模の御蔵が設けられている点は囲い込み型 と同じである。この御蔵と棟が直交するより小規模な建物が庭を囲 むように配置されている。これらの御蔵所も囲い込み型になる可能 性があったが、建物規模と敷地規模との不均衡によって平行型にな ったと考えられよう。敷地囲いがない浜に立地する鰺ヶ沢港の「濱 ノ御蔵」についても、建物配置のみを見ると藩政中期は平行型であ ったが、その後の減築によって型式が完成されなかったと見ること ができる。一方、青森港の「安方御蔵」は元来の平行型と見られる。 敷地囲いは明らかでないが、町蔵を併設したこともあり、弘前藩で は特殊な事例と言える。しかし、その実態や変遷などは不明な部分 が多いので、新たな史料の発見を待って検討したい。

以上のことから弘前藩御蔵所では、囲い込み型が標準形と考えら れる。

\subsection{2 戸口、庇}

藩政後期の弘前藩御蔵所の御蔵の戸口は 2 ケ所であったと考えら れた（Table 2)。このように戸口を少なくし、防犯等に配慮したと 推察される。囲い相互あるいは、戸口から戸口への移動は、内部通 路で可能であったので、戸口の庇は戸前庇でよかったと考えられる。 従って、弘前藩御蔵所では戸前庇が標準であったと考えられる。

長庇が設けられる建物を見ると、年貢米徴収を主な目的とした御 蔵所の場合、敷地奥の大蔵である（Fig. 3)。移出港の〈青森新町〉 の場合、庭の中心に位置する検査所である。このように長庇は、御 蔵所の中心となる建物に限定的に設けられていることがわかる。

\section{2 長庇の機能}

長庇を検査所や物資の仮置き場として用いた地域があったことを 前述した。年貢米徴収のみに用いられた大規模な弘前藩御蔵所の場 合、検查所が仮設であったことを前述したが、年貢米の検査が滞る 場合、この長庇を第二の検查所あるいは仮置き場として用いること ができる。小規模な御蔵所（Fig. 3778)）では、仮設の検査所は必 要なく、長庇が主たる検查所になったであろう。なお、長庇は、門 
から見て正面の最大規模の御蔵に設けられていたので、目につきや すく、物資運搬にも配慮されていたと考えらえる。一方、小規模な 御蔵所でも〈金木〉や〈床舞〉においては、長庇を設けず検查所を常設 した。

また、加賀藩領では、御蔵所において長庇による門の背後の庭と 敷地奥を結ぶ主動線の形成が見られるが ${ }^{3)}$ 、弘前藩の場合、荒天時、 搬入搬出の人の移動に内部通路が利用できるので、主動線を形成す るための長庇は必要なかったと考えられよう。このような内部通路 を有する御蔵は、我が国の豪雪地帯の他藩の御蔵所では確認できて いない。

迴米のため大量の米が集まる移出港では長庇の設置状況が異なっ た。〈青森新町〉の場合、敷地の中央に配置される検査所の平側 2 面 に「廊下」と呼ばれる下屋があったことを前述した。これは長庇と 見られる (Fig. 399)。検查所の空間を拡張するものであり、検查等 に用いられたと考えられる。一方、藩政中期の鯵ケ沢港「濱ノ御蔵」 の場合、全ての御蔵に長庇が見られた。敷地囲いのない「濱ノ御蔵」 では、各御蔵に長庇を設けて、御蔵毎に収納等の業務を行っていた 可能性がある。しかし、前述したように他の絵図史料では庇が見ら れず、このことについては、新たな史料の発見を待って詳しく検討 したい。

\section{5. まとめ}

本研究は、近世期の弘前藩御蔵所の空間構成に関して以下のこと を明らかにした。

年貢米徴収を主な目的とした御蔵所には御蔵役人の居所である御 長屋があり、門寄りに位置して蔵々とともに庭を囲んでいた。検查 所は、大規模な御蔵所では仮設小屋として設けられていた。一方、 長庇のない小規模な御蔵所や移出港の〈青森新町〉では常設の建物 であった。

建物配置の型式は、囲い込み型が多かったが、建物規模と敷地規 模の不均衡によって小規模の御蔵所などに平行型が派生した。移出 港の〈青森新町〉も、中庭の中心の検查所を除くと囲い込み型であ った。御蔵の庇は戸前庇が多く、豪雪地帯に顕著な長庇は中心的な 御蔵にのみ設けられていた。御蔵内部に間仕切りによって区画され た多くの囲いがあり、これらの囲いが戸口側の内部通路で結ばれて いた事例や、囲いのない事例があるなど、御蔵内部において戸口か ら戸ロへの通行が可能であったと推測された。

藩政後期の弘前藩御蔵所の標準形は、建物配置の型式は囲い込み 型で、御蔵は 2 ヶ所の戸口が開かれ、各戸口に戸前庇を有するもの であった。しかし、検查所が仮設小屋であった御蔵所や常設の検査 所を設けない小規模の御蔵所では、敷地奥にある最大規模の御蔵に 検查所や米俵の仮置き場として長庇が設けられたと考えられる。こ のような標準形の御蔵所の形成要因として、前記した弘前藩御蔵所 の御蔵内部の構造があげられる。このことから加賀藩御蔵所などに 見られた多くの長庇は必要なかったと考えられた。

以上、弘前藩御蔵所は、標準形を有し、豪雪地帯の他藩の御蔵所 に比べて長庇が中心的な建物にのみ設けられる点に特徴づけられる。 その形成要因として、内部通路と常設の検査所を設けない点があげ られる。

なお、藩政中期の鯵ケ沢港「濱ノ御蔵」において全ての御蔵に長
庇が見られた理由、〈青森安方〉の実態及び空間形成の要因について は新たな史料の発見を待って検討することとした。御蔵の内部構造 についても、同様に今後さらに検討していきたい。

\section{謝辞}

調査に協力いただいた弘前市立弘前図書館、同博物館、弘前市教 育委員会、津軽藩ねぷた村の方々に感謝申し上げる。

\section{参考文献}

1) Sagami, C. : Study on Okura at the magistrate' s Office of the Feudal Government Established in Ikuno-Ginzan Town in the Edo Period, Journal of Architecture and Planning (Transaction of AIJ), Vol. 81, No. 729, pp. 2487-2495, 2016. 11 (in Japanese)

2) Edited by Tottori Pref. : Tottorikenshi (History of Tottori Pref.), Vol. 12, Tottori Pref., 1979 (in Japanese) 鳥取県編：鳥取県史 12, 鳥取県, 1979

3) Sagami, C. : Study on Spatial Structures of Okura-syo Owned by Kaga Domain in the Edo Period -About the Spatial Formation by "Nagahisashi” (Long Eaves that cover around the entrance)-, Journal of Architecture and Planning (Transaction of AIJ), Vol. 83, No. 743, pp. 93-101, 2018. 1 (in Japanese)

4) Sagami, C.: Principles of Spatial Structures and Regional Characteristics of Okura-syo Owned by the Kaga Domain in the Edo Period -By the Analysis of the Extension Method-, Journal of Architecture and Planning (Transaction of AIJ), Vol. 82, No. 732, pp. 507-517, 2017. 2 (in Japanese)

5) Sagami, C. : Spatial Structures of Okura-syo 0wned by the Tottori Domain in the Edo Period, Journal of Architecture and Planning (Transaction of AIJ), Vol. 81, No. 724, pp. 1373-1383, 2016. 6 (in Japanese)

6) Sagami, C.: Spatial Structures of Okura-syo Owned by the Kaga Domain Located in the Kaga Province in the Edo Period, Journal of Architecture and Planning (Transaction of AIJ), Vol. 79, No. 705, pp. 2517-2526, 2014. 11 (in Japanese)

7) Sagami, C. : Determinants of Types of Okura-syo Owned by the Kaga Domain Located in the Noto Province in the Edo Period, Journal of Architecture and Planning (Transaction of AIJ), Vol. 78, No. 688, pp. 1389-1397, 2013. 6 (in Japanese)

8) Sagami, C. : Spatial Structures of Okura-syo Located in the Kuzuryu River Basin in the Edo Period -By Comparison between the Fukui Domain and the Katsuyama Domain-, Journal of Architecture and Planning (Transaction of AIJ), Vol. 78, No. 687, pp. 1143-1150, 2013. 5 (in Japanese)

9) Sagami, C. : Spatial Structures of Okura-syo Owned by the Kaga Domain Located in the Noto Province in the Edo Period, Journal of Architecture and Planning (Transaction of AIJ), Vol. 77, No. 682, pp. 2865-2872, 2012. 12 (in Japanese)

10) Sagami, C. : Spatial Structures of Okura-syo Owned by the Kaga Domain Located in the Ettyu Province in the Edo Period, Journal of Architecture and Planning (Transaction of AIJ), Vol. 77, No. 676, pp. 1471-1478, 2012. 6 (in Japanese)

11) Sagami, C. : Spatial Structure of Okura-syo Owned by the Nagaoka Domain Located in the Shinano River Basin in the Edo Period, Journal of Architecture and Planning (Transaction of AIJ), Vol. 76, No. 669, pp. 2191-2197, 2011. 11 (in Japanese)

12) Sagami, C. Spatial Structure Characteristics of Okura-dokoro Owned by the Morioka Domain Located on the Kitakami River in the Edo Period, Journal of Architecture and Planning (Transaction of AIJ), Vol. 75, No. 657, pp. 2693-2699, 2010. 11 (in Japanese)

13) Sagami, C. : A Study on the Spatial Structures of Edo Period' s River Side Water Transportation Facilities Owned by Aizu Domain -In Case of Shiokawa Okura-tokoro-, Journal of Architecture and Planning (Transaction of AIJ), Vol. 75, No. 653, pp. 1721-1727, 2010. 7 (in Japanese)

14) Sagami, C. : Spatial Structure of Mikura-yashiki Owned by the Yonezawa Domain Located on the Mogami River in the Edo Period, 
Journal of Architecture and Planning (Transaction of AIJ), Vol. 74, No. 641, pp. 1655-1660, 2009. 7 (in Japanese)

15) Sagami, C., Iibuchi, K. and Nagai, Y.: Okuraba in Settlements Formed in the Kitakami River Basin in Sendai Fief -Case Study on the Wegedorf-, Minzoku-kenchiku(Folk Architecture), No. 130, pp. 15-24, 2006. 11 (in Japanese)

16) Sagami, C., Iibuchi, K. and Nagai, Y. : A Study of the Spatial Structure of Settlements that was formed in the Edo period in the river basin -A Case Study on Itayanoki Village on the Iwaki River-, Proceedings of AIJ Tohoku Chapter Architectural Research Meeting, No. 71, pp. 281-288, 2008. 6 (in Japanese)

17) Sagami, C., Iibuchi, K. and Nagai, Y. : A Study of the Spatial Structure of Settlements that was formed in the Edo period in the river basin -A Case Study on Gosyogawara Village on the Iwaki River-, Proceedings of AIJ Tohoku Chapter Architectural Research Meeting, No. 71, pp. 289-296, 2008. 6 (in Japanese)

18) Edited by Editorial board of "History of Azigasawa Town": Azigasawa tyoshi (History of Azigasawa Town), Vol. 1, Azigasawa Town, 1984 (in Japanese)

鯵ヶ沢町史編さん委員会編：鯵ヶ沢町史第 1 巻, 鯵ヶ沢町, 1984

19) Edited by Fukushi, T. : Itayanagikyodoshi (Local history of Itayanagi Town), Itayanagi Town Office, 1940 (in Japanese) 福士貞蔵編：板柳町郷土史，板柳町役場， 1940

20) Edited by Gosyogawara Town: Gosyogawaratyoshi (History of Gosyogawara Town), Gosyogawara Town, 1935 (in Japanese) 五所川原町編：五所川原町誌，五所川原町， 1935

21) Edited by Editorial board of "History of Fujisaki Town": Fujisaki tyoshi (History of Fujisaki Town), Vol. 1, Fujisaki Town, 1996 (in Japanese)

藤崎町誌編さん委員会編：藤崎町誌第 1 巻, 藤崎町, 1996

22) Nagasawa, T. : Tsugarushi (History of Tsugaru), Vol. 3, Association of Cultural Property Preservation by Aomori Pref. , 1974 (in Japanese)

永沢得右衛門：津軽史第三巻，青森県文化財保護協会，1974

23) Edited by Editorial board of "History of Aomori City": Aomorishishi shiryohen (History of Aomori City, Source book), Vol. 4, Aomori City, 2004 (in Japanese)

青森市史編集委員会編：新青森市史資料編 4, 青森市，2004

\section{注}

注 1) 検查所は、年貢米の量や重さ、米の品質などを検査する場所である。そ の呼称は地域によって異なった。

注 2) 文献 1), p. 2489

注 3) 弘化 4 年（1847） 2 月 27 日の「在方諸事控」（文献 2), pp. 327 328 所 収）に、「御来屋御蔵此度之御迴米千百式拾五俵、去ル七日御廻米下作廻前 田源三郎立会御手船寛肇丸賄政右衛門え相渡し、計り屋尾垂（庇）等え為 差置、(後略)」とある。

注 4) 加賀藩、鳥取藩、福井藩、幕府領飛騨国及び生野銀山

注 5) 文献 3), p. 98

注 6) 常設の検查所が見られた藩等は、盛岡藩(「斗御小屋」)、仙台藩(「吹屋」)、 会津藩塩川御蔵所 (「計屋」)、長岡藩 (「斗蔵」)、加賀藩 (「計蔵」)、鳥取藩 $(\lceil$ 計屋」)、勝山藩 (「計場」)、幕府領生野銀山（「斗場」）があげられる。上 記がなく、代わりに御蔵の戸前に長庇などが見られる藩等は、米沢藩 (「取 次」)、福井藩 (「附属下屋」)、幕府領飛騨国（「土庇」）があげられる。

なお、加賀藩の場合、検查所がないかつ、長庇が 1 ケ所もしくはなしの 御蔵所は〈飯田〉、〈乙ヶ崎〉、〈滑川東〉、〈滑川西〉、〈石田〉、〈道下〉、〈富木 〉、〈大町〉、〈所口〉の 9 ケ所で、全体（４３ｒ所）の 2 割程に止まる。加賀 藩領において検查所は、村々の普請によって増築されていった。

注 7) 文献 18), p. 235 掲載

注 8）「国日記」, 寛政 7 年（1795）12月 10 日の条〈藤崎〉や〈浪岡〉の各 2 万

2 千俵が青森港の御蔵所へ、〈五所川原〉の 2 万 2 千俵、〈板屋野木〉の 1 万 8 千俵、〈石渡〉の 1 万 1 千俵、〈床舞〉の 9 千俵、〈高杉〉や〈金木〉の各 8 千俵、 〈木造〉の 7 千俵、〈八幡〉の 6 千俵がく䱵ヶ沢〉へ送られたことが知られる。
上記の廻米量は一概に御蔵所の規模を表すものではないが、Fig. 3 の見 取図に記される各御蔵所における御蔵の長さの合計を比較すると、〈藤崎〉 70 間、〈板野野木〉「上蔵」 62 間（藩政後期の〈板野野木〉は 84 間）、〈石 渡〉 44 間、〈床舞〉 20 間であり、これらは大凡廻米量に比例しているので、 迴米量から御蔵所の規模を見ても大過ないと考えられる。

注 9) 弘前城下に「弘前三蔵」と呼ばれる 3 ケ所の蔵場があった。「亀甲御蔵」 はその一つである。しかし、これらの蔵場の建物配置が知られる史料は見 られない。

注 10) 弘前市立弘前図書館蔵 本図は原史料を書き写したものと見られる(原 史料の所在は不明)。本書の表紙に「中村 (良之進) 氏所蔵」とある。本図 には作製者による追記も見られる。各図に「(最初ノ古図)」と追記されて いる。Fig. 3(1)〜 (4)の他に、〈木造〉の見取図が所収されている。〈木造〉は、 代官所の敷地内にあり、郷蔵も併設されているため、型式の検討は難しい。

注 11) 弘前市立弘前図書館蔵 本図は墨書きによる写し図である。本書の表 紙に「中村氏秘蔵」と押印されている。移出港の御蔵所（Fig. 399)の他に 〈青森安方〉、「鰺ケ沢浜御蔵」）や比較的小規模の御蔵所、複数の御長屋の 見取図が所収されている。なお、く青森安方〉、魼ヶ沢浜御蔵」に関しては、 敷地境界が描かれてなく、御蔵は細部が省略されており、建物の種別や戸 口・庇も不明。

注 12) 図版出典Fig. 3 参照

注 13) 享保期（1716～1735）頃の「鰺ケ沢町絵図」（Fig. 4111-1）には、「濱ノ 御蔵」(A)、「沢ノ御蔵」(B)、御仮屋の敷地内に御蔵など $(C)$ 、漁師町の外孔 に「御船蔵」(D) が描かれている。文化年間 $(1804 \sim 1817)$ 以前の「鰺ケ沢 町絵図」(Fig. 4111-2) も同様であるが、上記 B には「沢ノ御米蔵」、Cには 「御米蔵」や「材木御蔵」とあり、これらも年貢米徵収や迴米に用いられ た可能性がある。しかし、B 及び C の御米蔵は 1 棟であり、戸口も描かれて いないので、型式等の検討は難しい。

注 14）〈板屋野木〉に関する Fig. 3(2)左図や〈五所川原〉に関する明治維新 時図では、道沿いに描かれている長屋が該当すると見られる。〈石渡〉は、 表現の異なる桁行 5 間の建物が御長屋と推測される。

注 15）〈青森新町〉については、貞享期（1684～）から元禄元年（1688）まで の間に作製された「青森町絵図」(Fig.49) の御蔵所の外に「御蔵奉行」 や「御目付」と記される建物が各 2 軒見られる。このように〈青森新町〉に おいて役人の居所は個別に設けられており、長屋ではなかった。

注 16）「苫小や」とは、苫（茅などを苽のように編んだもの。小家屋を覆うの に用いられた）で覆われた小屋と考えられる。

注 17) 前掲注 8)

注 18) 文献 10),p. 1472 本稿において筆者は、収納以外の蔵も含めて 4 棟が 中庭（門に接しない内庭）を形成する御蔵所を囲い込み型に類型化した。

注 19) 文献 10),p. 1472 本稿において筆者は、半数以上の棟が庭を挟んで平 行関係に配置された御蔵所を平行型に類型化した。

注 20) 文献 19), p. 247

注 21) 図版出典.Fig. 3(2)右図参照

注 22) 筆者は、過去の研究において御蔵が 1 棟の御蔵所は発展過程と考えら れるので、型式の検討から除外した。

注 23) なお、前掲注 11) には、作製年不明の見取図「鯵ヶ沢濱御蔵」が所収さ れている。しかし、「冨根丁」と記されていることから、前掲注 13)の船蔵 である可能性が高い。冨根町の成立は文化 2 年（1805）であるので、これ 以後に作製されたものと推測される。

注 24) 御蔵を管理使用する観光施設「津軽藩ねぷた村」には、道路側の平側中 央部に戸口があったことが伝えられている。この部分の室内側に框材が見 られるが、開口は柱及び土壁で塞がれており、外壁面に庇は見られない。 注 25）1つの区画は、加賀藩領では囲い、飛騨国の幕府領では房と呼ばれた。 注 26) 内部の梁行中央に独立柱がある。独立柱の桁行方向の間隔は 3 間で、独 立柱は都合 4 本である。これらに貫の痕跡は見られない。なお、小屋組は 合掌組なので、間仕切り壁を設け難い構造である。但し、桁行方向の一部 の側柱に貫や水平梁の痕跡がある。貫の痕跡は、桁行方向の中央スパンに あり、前述の戸口跡の辺りなどである。水平梁の痕跡は、 3 本の側柱と 1 本の独立柱に見られるのみである。

注 27) 文献 3), p. 93, pp. 96-97

注 28$)$ 橋津御蔵所の建築遺構「古御蔵」, 天保 14 年 (1843)

注 29）囲いは、間口 3 間、奥行 3 間の広さとなる。

注 30) 桁行きが最長の御蔵で比較すると、〈藤崎〉は南蔵 27 間、〈五所川原〉 
は 28 間、〈青森新町〉は 27 間に対して戸口が 2 ヶ所である。〈浪岡〉の御 蔵の長さは知られない。

\section{図版出典}

Fig. $1 ， 2$ 筆者作製

Fig. 3 (2)右図、(3)、(4)左図: 八木橋文庫「津軽藩政時代之公衙蔵庫古圖式」, 作製年不明, 弘前市立弘前図書館蔵

(1)御長屋図、(5)～(9) : 八木橋文庫「津軽藩諸役所倉庫圖式一部」，作製年 不明, 弘前市立弘前図書館蔵

(2)左図 : 「板屋ノ木御蔵惣図」, 元禄 5 年 (1692), 弘前市立博物館蔵

(4)右図 : 文献 20), p. 237 より転載。御蔵所の年代について本図に明治維新 当時とある。

(1)文献 21), p. 166 掲載の「藤崎御蔵構之図」には、建物の名称、蔵の長さ、 庇、戸口、空が記されている。また、本図の建物配置は、前掲注 10) 八木橋 文庫「津軽藩政時代之公衙蔵庫古圖式」を参照したものと聞かれた。「計御 倉」(点線）は後者による。これらを基に 1 間を $0.5 \mathrm{~mm}$ として作製した。本 図の建物の種別及び配置は、寬政 11 年（1799）の「藤崎村戸数改図」(藤 崎町蔵）に描かれる御蔵所のそれと同じであるので、本図から藩政後期の 御藏所を見ても大過ないと考えられる。

御長屋は、八木橋文庫「津軽藩諸役所倉庫圖式一部」のうち「藤崎御蔵 御長屋之圖」 各部屋の広さは、御蔵奉行組合大凡 12 畳、立合及び土間 8 畳、升取居所 6 畳と見て取れる。原図の写真に記号、解読文字を記入した (以下(2)右図, (3), (4)左図, (5)〜 (9)も同じ)。

(2)左図 原図には、柱、間仕切り、戸口が寸法に注意して描かれている。 敷地の北側に「四間二四拾五間新御蔵」と記される建物がある。この他の 建物には名称が記されていない。御蔵所の建物について文献 22) , p. 245 の 元禄 3 年（1690）の八月十二日の条に、「(前略) 上蔵も觩相二候へ八如何 奉存候、可被仰付哉之旨、野宫理右衛門申立二付、同役相談之上靯負一相 達、下之蔵入用積之格を以申立候通普請申付之、(後略)」と記されている。 上蔵の後に、下之蔵が設けられていることから、前記の「新御蔵」は、下 之蔵であったことが推測される。原図の写真のトレースに記号、解読文字、 括弧の文字を記入した。本図の幹線道路沿いの敷地辺に「表通り百拾間五 尺」、奥行き方向の敷地辺に「北通り二拾二間五尺」と記されているので、 縮尺を大凡 1 間を $0.5 \mathrm{~mm}$ とした。方位は、原図に記されていないので、現 在の地図を用いて旧道から求めた。

(2)右図 前掲注 10)八木橋文庫「津軽藩政時代之公衙蔵庫古圖式」のうち 「板柳御蔵建構之圖」文政 2 年 (1819) の「卯年改表」(文献 19)，pp. 101 ～102 掲載）に、「一、御蔵三ヶ棟 但シ一棟長廿八間、幅四間御長屋共」 とあり、本図は、これらが描かれていると見られる。なお、明治維新後の 御蔵所廃止時も 3 棟であった (文献 19) , p. 247)。従って、本図から藩政後 期の御蔵所を見ても大過ないと考えられる。本図に建物等の長さが記され ていないので、無縮尺とした (以下(3), (4), (5), (7)も同じ)。

(4)左図「西新藏」などが書き足され、明治維新当時の建物配置になって いる。

(5)八橋文庫「津軽藩諸役所倉庫圖式一部」のうち 本図に御蔵所の名称 は記されていないが、金木川が見られることから、〈金木〉と考えられる。 (6)八木橋文庫「津軽藩諸役所倉庫圖式一部」のうち「床前御蔵構之圖」本 図に「倉虞并長屋明治四年未年御不用二付調不申上候（後略）」とあり、「倉 虞斗場共御拂二相成候」と朱書きされている。しかしながら、御蔵所の空 間構成要素は藩政期と同じであるので、本図から幕末期の御蔵所を見ても 大過ないだろう。建物の長さが記されているので、縮尺を大凡 1 間を $0.5 \mathrm{~mm}$ とした（以下(8), (9)も同じ)。方位は不明（以下(7), (8)も同じ)。

(9)八木橋文庫「津軽藩諸役所倉庫圖式一部」のうち「青森御蔵構之圖」本 図に、「弘化元辰ノ八月改之」と記されており、藩政後期の御蔵所の様子が 知られる。また、本図には水路で隔てられ橋で結ばれた場所にも「新御蔵」 など 2 棟の御蔵が見られ、御蔵所が拡張したことが知られる。

Fig. 4 (9「青森町絵図」, 弘前市立博物館蔵 本図の作製年について文献 23) は、貞享期（1684～) から元禄元年（1688）までの間としている。 原図の写真に記号、解読文字を記入した（以下(10も同じ）。 (10前掲注 11)

(11)-1「鯵ヶ沢町絵図」, 鯵ヶ沢町教育委員会蔵 作製年について光信公の館 ホームページは、寺院、町名の配置、人名等から享保期（1716～1735）頃 と推定している。

http://www. town. ajigasawa. lg. jp/mitsunobu/illustration_a. html
(2017 年 10 月時点)

上記ホームページ掲載写真に記号、解読文字を記入した（以下(11)-2 も同 じ)。

(11)-2「鯵ヶ沢町絵図」, 鰺ヶ沢町教育委員会蔵 作製年について前掲光信 公の館ホームページは、寺院や町名の配置などから文化年間 $(1804 \sim 1817)$ 以前と推定している。

Fig. 5 筆者撮影 旧御蔵の北面、道路側。 


\title{
STUDY ON SPATIAL STRUCTURES OF OKURA-SYO OWNED BY HIROSAKI DOMAIN IN THE EDO PERIOD
}

\author{
Chikao SAGAMI ${ }^{* 1}$ \\ ${ }^{* 1}$ Assoc. Prof., Dept. of General Engineering, National Institute of Technology, Sendai College, Dr.Eng.
}

Chapter 1: The purpose of this study is to clarify the characteristics of spatial structures of Okura-syo owned by Hirosaki domain, and the factors of forming the space. For that purpose, I noticed the inspection station and the eaves of Okura.

Chapter 2: The previous studies and the procedure of this study were shown. In the Hirosaki domain territory, there were the Okura-syo for collecting the tax rice and transporting the rice by ship to Osaka or Edo (the latter is called "Kaimai"). There is an only architectural remains in Hirosaki city. That was one of the several Okura in the Kiko-Okura-syo in Hirosaki castle town. That Okura was renovate. But, we have the drawings of eleven Okura-syo. Those Okura-syo were targeted on this research.

Chapter 3: The spatial structures of each Okura-syo were shown. In the Okura-syo for only collecting the tax rice, there was essential "Onagaya”(a row house used by officers relating to Okura-syo). The inspection station in large-scale Okura-syo, was temporary hut. In all the Okura-syo in Hirosaki domain territory, the okura-syo that the permanent inspection station existed, were confirmed three. Two of these were small-scale Okura-syo that were used for only collecting the tax rice. And one of these was large-scale Okura-syo at export ports. There were many enclosure type as for the type of building arrangement. The others were parallel type. The eaves of Okura could be classified into the following two categories. The first one is long eaves, which covers around the entrance, the second one is "Tomae-hisashi", which covers only the entrance. In the each Okura-syo, there were many 'Tomae-hisashi”. On the other hand, the long eaves was one in the each Okura-syo. In the Itayanogi-okura-syo of the year 1692, although the entrance of Okura was two, the inside of Okura was divided space into more than two partitions. For that reason, in the inside of Okura, there was a corridor along the doors. In old mud-walled warehouse that was an okura in kiko-okura-syo in the last days of the Tokugawa shogunate, there was no partition. In those Okura's inside, the workers were able to pass from a door to next door.

Chapter 4: I examined about the standard form of Okura-syo owned by Hirosaki domain, and the function of long eaves that was set to front of Okura. As a result, the following standard form of Okura-syo owned by Hirosaki domain had clarified. The first one, type of building arrangement was the enclosure type. The second one, in all Okura, the entrance was two, the eaves were "Tomae-hisashi". But, the long eaves were set to the Okura (that arranged at the back of site) for inspection and place of rice straw bag, when the permanent inspection station was not built.

Chapter 5: In conclusion, it developed that Okura-syo in Hirosaki domain territory were characterized by following two things. The first one, there was a standard form. The second one, the only long eaves were provided on the main building of Okura-syo, in comparison with Okura-syo in the heavy snowfall area in Japan. As the factors of forming the space, it was mentioned that there was a passage inside of Okura, and the permanent inspection station was not built. 